THURSDAY, OCTOBER 6, I9IO.

\section{THE MAMMALS OF MANITOBA.}

Life-histories of Northern Animals: an Account of the Mammals of Manitoba. By Ernest Thompson Seton. Vol. i., Grass-Eaters. $\mathrm{P}_{\mathrm{B}} . \quad \mathrm{xxx}+673$. Vol. ii., Flesh-Eaters. Pp. xii $+674-1267$. (London: Constable and Co., Ltd., I910.) Price $£ 3$ i3s. 6d. net.

$\mathrm{SO}$ far as this country is concerned, it is a great $S$ pity that Mr. Seton did not include in his admirable life-histories the whole mammalian fauna of North America, as the restriction of the species to those inhabiting a particular area can scarcely fail to be faulty in the eyes of English readers, who will miss such well-known animals as the big-horn sheep, white goat, Columbian black-tailed deer, and the brown bears and caribou of Alaska. It is likewise a matter for regret that the whole of the table of contents is included in the first volume, instead of the portion relating to the Carnivora being reserved for the second. Except this very small modicum of fault-finding, 1 have nothing but commendation to bestow on these handsome volumes, which, it may be presumed, are an English edition of the work issued last year in America under the same title.

The mammals of Manitoba are fifty-nine in number, and of these the author describes the life-history in his own inimitable manner, and with a wealth of detail that leaves little, if anything, for future field naturalists to record. The great feature of the work is, of course, that it is the result of personal observation and first-hand knowledge, acquired during wanderings extending over a long series of years, and embracing a very large portion of the North American continent. The map of his travels shows, in fact, that Mr. Seton has explored the whole of the United States, from ocean to ocean, so that the red lines which mark his route form a perfect network. Southward he has touched the Mexican border, while northward he has visited Labrador on the east, and on the west has made a single traverse to the heart of the Mackenzie district. And it is these extensive journeys, with the knowledge thereby acquired, that intensifies our regret that he did not see fit to make his work cover the whole North American mammal fauna. In spite of the almost omniscient character of his personal knowledge of the habits and distribution of the animals of which he writes, the author has been at the pains to quote the names of observers by whom special traits were first recorded.

In addition to his well-known power of conveying important scientific information in most attractive and popular language, Mr. Seton enjoys the great advantage of being a skilled artist, so that he is able to present to his readers portraits of the animals in the particular pose which he considers most characteristic and interesting. The amount of labour he has expended on artistic work may be inferred from the fact that the whole of the 560 illustrations were drawn with his own pencil. Such sketches are, in my opinion, infinitely superior to photographs, which too NO. 2 I 36 , VOL. 84$]$ frequently do not bring out the characteristic features which the describer desires to emphasise. That many of these illustrations, if I mistake not, have appeared in other publications, testifies to public appreciation of their artistic merit.

In the space at my disposal it is quite impossible to attempt anything in the way of a critical review of these two bulky quarto volumes, and I shall therefore content myself with noticing some of the author's observations relating to the larger species which appear of special interest.

By far the most characteristic American type of big game is undoubtedly the prongbuck, a species the distributional area of which has been reduced by about one-half, and the numbers of which were estimated by the author in 1900 not to exceed, at most, 100,000 , of which half must be in Mexico. And yet from the accounts of travellers of no earlier date than 1868 it seems probable that these graceful antelopes, as they are locally called, actually outnumbered the bison in the days of its prime. Taking the number observed in one particular district as a basis, the author calculates that, on a low estimate, there must have been over 40 millions on the great plains. Since 1900 these antelopes, in spite of reported local increases, have probably suffered a further serious decrease, the number in Wyoming in 1905 being estimated at not more than one-fourth of what it was five years previously.

As regards the extermination of the bison, $\mathrm{Mr}$. Seton, although as a naturalist regretting the event, takes what may be called the practical view of the subject, and declares it to have been absolutely inevitable. The plains were required by the advance of civilisation, and the supporting of vast herds of stupid bison, ready to stampede in an overwhelming mass on the slightest alarm, was not the best use to which they could be put. On the testimony of two independent observers, he asserts that blizzards, especially those of $187 I^{-2}$ and $1880-1$, had a share in the extermination of the bison, one of the two witnesses stating that the Dakota blizzard was more destructive to the herds than the Indians. Since, however, blizzards are only occasional events, $\mathrm{Mr}$. Seton doubts if their destructiveness was equal to that of agencies working with greater regularity.

In concluding this brief notice of a first-class work, it may be noted that the author is a firm believer in the evolution of the mind of man from that of animals below him in the zoological scale.

R. L.

\section{THE CARE OF TREES.}

The Care of Trees in Lawn, Street, and Park. By Bernard E. Fernow. Pp. $x+392$. (New York: Henry Holt and Co., Igro.)

LTHOUGH there is scarcely a garden or park $\mathrm{A}$ of any pretensions in this country which does not contain within its boundaries one or more trees particularly valued for their interest, beauty, or associations, how rarely do their owners ever take any steps to keep them in health, and thus prolong their term of years. The care of trees, indeed, more 